\title{
Penerapan Metode Pembelajaran Inquiry dan Discovery Pada Materi Sistem Ekskresi Pada Manusia di SMP Negeri 3 Tondano
}

\author{
Sanci Mangar ${ }^{1 *}$, Ni Wayan Suriani² \\ 1,2Jurusan Pendidikan IPA, FMIPA, Universitas Negeri Manado \\ *e-mail: mangarsanci123@gmail.com
}

\begin{abstract}
Abstrak. Penelitian ini bertujuan untuk mengetahui apakah terdapat perbedaan ratarata hasil belajar siswa yang menggunakan metode pembelajaran inquiry dan discovery pada materi sistem ekskresi di SMP Negeri 3 Tondano. Metode yang digunakan dalam penelitian ini adalah metode eksperimen semu (quasi experimen) dengan rancangan penelitian pretest posttest group design. Penelitian ini menggunakan dua kelas, yaitu kelas VIII-A menggunakan metode inquiry dan kelas VIII-C menggunakan metode discovery. Hasil penelitian menunjukkan thitung sebesar 2,39. Data tabel distribusi t pada 0,05 dengan derajat kebebasan $\mathrm{n} 1+\mathrm{n} 2-2=57$, maka diperoleh t tabel sebesar 2,00. Jadi diperoleh thitung $=2,39>t_{\text {tabel }}=2,00$. Berdasarkan kriteria pengujian, jika thitung lebih besar dari tabel, maka $\mathrm{H}_{0}$ ditolak yang berarti $\mathrm{H}_{1}$ diterima. Sehingga disimpulkan bahwa terdapat perbedaan rata-rata hasil belajar siswa pada materi sistem ekskresi pada manusia antara kelas yang menggunakan pembelajaran dengan meteode inquiry dan kelas yang menggunakan pembelajaran dengan metode discovery.
\end{abstract}

Kata kunci: inquiry, discovery, sistem ekskresi pada manusia, hasil belajar

\begin{abstract}
This study aims to determine whether there is a difference in the average learning outcomes of students using the inquiry and discovery learning methods on the excretion system material at SMP Negeri 3 Tondano. The method used in this study was a quasi-experimental method with a pretest-posttest group design. This study used two classes, namely class VIII-A using the inquiry method and class VIII-C using the discovery method. The results showed that $t_{\text {count }}$ was 2.39. Distribution t-table data at 0.05 with degrees of freedom $n 1+n 2-2=57$, then the $t$ table is 2.00. So we get $t_{\text {count }}=$ $2.39>t_{\text {table }}=2.00$. Based on the test criteria, if $t$ count is greater than $t$ table, then $H_{0}$ is rejected, which means $H_{1}$ is accepted. So it can be concluded that there is a difference in the average student learning outcomes in the excretion system material in humans between the class that uses the inquiry method and the one that uses the discovery method.
\end{abstract}

Keywords: inquiry, discovery, excretion system in humans, learning outcomes

Diterima 01 Desember 2020 | Disetujui 30 Desember 2020 | Diterbitkan 31 Desember 2020

\section{PENDAHULUAN}

Pendidikan sebagai suatu kegiatan yang sistematis dan sistemik terarah kepada terbentuknya kepribadian siswa (Udin, 2011). Proses pendidikan berlangsung melalui tahapan-tahapan yang berkesinambungan dan sistemik. Oleh karena itu, dapat tercipta secara langsung dalam semua situasi, kondisi, dan lingkungan yang saling mengisi (lingkungan sekolah, rumah, dan masyarakat).

Proses pembelajaran IPA terpadu, sangatlah memerlukan metode dan strategi pembelajaran yang tepat. Artinya, penerapan metode yang harus melibatkan siswa seoptimal mungkin, baik secara intelektual maupun emosional. Hal ini disebabkan karena pembelajaran IPA terpadu menekankan pada keterampilan proses, guru harus 
menguasai metode dan strategi-strategi pembelajaran serta dapat menciptakan suasana kelas yang membuat siswa termotivasi aktif dalam belajar, sehingga dapat meningkatkan hasil belajar (Suherman, 2013).

Hasil observasi awal dengan melakukan wawancara pada guru IPA di SMP Negeri 3 Tondano diperoleh informasi bahwa hasil belajar IPA masi kurang karena $75 \%$ nilai siswa berkisar antara 60-65, dan belum mencapai Kriteria Ketuntasan Minimum (KKM) yang ditetapkan. Oleh karena itu, perlu dipilih suatu metode pembelajaran yang dapat menunjang kelancaran proses pembelajaran dengan memperhatikan aspek guru dan keinginan siswa tersebut. Salah satu metode yang perlu diterapkan adalah metode pembelajaran inquiry dan discovery.

Metode pembelajaran inquiry merupakan metode penemuan yang menuntut pengetahuan yang lebih kompleks dibandingkan dengan pembelajaran konvensional. Selanjutnya, metode pembelajaran discovery merupakan metode pengajaran yang menitikberatkan pada aktivitas siswa dalam belajar. Jadi, kedua metode ini sama-sama menitikberatkan pada proses belajar siswa aktif. Atau dengan kata lain, kedua metode ini menempatkan siswa sebagai pusat pembelajaran sedangkan guru hanya sebagai pembimbing dan fasilitator bagi siswa dalam proses pembelajaran (Tompo, Ahmad \& Muris, 2016).

Pada metode pembelajaran inquiry, siswa dengan proses mentalnya sendiri dapat menemukan suatu konsep, sehingga menyusun rencana percobaan dilakukan atas kemampuannya sendiri. Dalam metode ini, permasalahan dilontarkan oleh guru, cara pemecahan masalah ditentukan oleh siswa, penemuan kesimpulan juga dilakukan oleh siswa (Mulyasa, 2013). Tidak jauh berbeda dengan metode inquiry, dalam metode pembelajaran discovery, guru hanya bertindak sebagai pembimbing dan fasilitator yang mengarahkan siswa untuk menemukan konsep, dalil, prosedur, algoritma dan semacamnya.
Metode pembelajaran discovery mengutamakan cara belajar siswa aktif, berorientasi pada proses, mengarahkan sendiri, mencari sendiri dan refleksi (Ilahi, 2012).

Adapun yang menjadi tujuan dari penelitian ini adalah untuk mengetahui perbedaan hasil belajar siswa pada materi sistem ekskresi pada manusia dengan penerapan metode pembelajaran inquiry dan discovery di SMP Negeri 3 Tondano.

\section{METODE PENELITIAN}

Penelitian ini dilaksanakan di SMP Negeri 3 Tondano. Variabel dalam penelitian ini ada dua, yaitu: variabel bebas yaitu metode pembelajaran inquiry dan discovery dan variabel terikat yaitu hasil belajar IPA. Populasi dalam penelitian ini adalah seluruh siswa kelas VIII SMP Negeri 3 Tondano tahun ajaran 2019/2020 yang berjumlah 60 siswa. Sampel yang diambil adalah siswa kelas VIII-A berjumlah 30 siswa yang merupakan kelompok eksperimen 1 menggunakan metode inquiry dan kelas VIII-C berjumlah 30 siswa yang merupakan kelompok eksperimen 2 menggunakan metode discovery.

Metode yang digunakan dalam penelitian ini adalah eksperimen semu (quasi eksperimen) dengan menggunakan rancangan penelitian pretest posttest only group design. Adapun rancangan tersebut dapat dilihat pada Tabel 1.

Tabel 1. Rancangan penelitian

\begin{tabular}{llll}
\hline Kelas & Pretest & Perlakuan & Posttest \\
\hline Inquiry & $\mathrm{O}_{1}$ & $\mathrm{X}_{1}$ & $\mathrm{O}_{3}$ \\
Discovery & $\mathrm{O}_{2}$ & $\mathrm{X}_{2}$ & $\mathrm{O}_{4}$ \\
\hline
\end{tabular}

Keterangan

$\mathrm{X}_{1}$ : metode inquiry

$\mathrm{X}_{2}$ : metode discovery

$\mathrm{O}_{1}$ : pretest untuk kelompok yang diajarkan dengan metode inqury

$\mathrm{O}_{2}$ : pretest untuk untuk kelompok yang diajarkan dengan metode discovery

$\mathrm{O}_{3}$ : posttest untuk kelompok yang diajarkan dengan metode inquiry

$\mathrm{O}_{4}$ : posttest untuk kelompok yang diajarkan dengan metode discovery 
Teknik pengambilan data dalam penelitian ini dilakukan dengan cara tes awal (pretest) dan tes akhir (posttest). Instrumen tes yang digunakan sebelumnya diuji validitas dan reliabilitas instrumen. Selanjutnya, analisis data yang digunakan adalah uji-t melalui uji normalitas, uji homogenitas dan uji hipotesis. Uji-t dengan taraf signifikan $a=$ 0,05 .

\section{HASIL DAN PEMBAHASAN Hasil Penelitian}

Penelitian ini melibatkan dua data yang diambil adalah hasil pretest dan posttest untuk mengetahui apakah terdapat perbedaan hasil belajar siswa pada materi sistem ekskresi pada manusia dengan penerapan metode pembelajaran inquiry dan discovery di SMP Negeri 3 Tondano. Data hasil pretest kelas eksperimen 1 menyebar antara 2572 sedangkan hasil pretest kelas eksperimen 2 menyebar antara 16-65. Kedua nilai tersebut menunjukkan bahwa baik kelas eksperimen 1 dan kelas eksperimen 2 mendapat nilai dibawah KKM 75. Selanjutnya, diberikan perlakuan, kemudian dilakukan posttest untuk melihat perbandingan hasil belajar siswa sebelum dan setelah perlakuan. Hasil postest diperoleh siswa kelas eksperimen 1 menyebar antara 72-96 dan nilai tersebut menunjukkan bahwa sebanyak 22 siswa mencapai KKM 75 dan 8 siswa yang tidak mencapai KKM 75 . Sedangkan hasil posttest kelas eksperimen 2 menyebar antara 43-76 dan nilai tersebut menunjukkan bahwa sebanyak 3 siswa mencapai KKM 75 dan 27 siswa yang tidak mencapai KKM 75 . Artinya terdapat peningkatan hasil belajar IPA siswa setelah diberikan perlakuan menggunakan metode pembelajaran inquiry dan discovery. Perbedaan rata-rata pretest dan posttest kedua kelompok tersebut dilihat pada Tabel 2 dan Tabel 3.
Tabel 2. Hasil pretest dan posttest kelas eksperimen 1 (metode inquiry)

\begin{tabular}{llll}
\hline Statistik & Pretest & Posttest & Selisih \\
\hline Jumlah siswa & 30 & 30 & 30 \\
Skor & 72 & 96 & 24 \\
maksimum & & 72 & 47 \\
Skor minimum & 25 & 2404 & 933 \\
Jumlah & 1471 & 80,13 & 31,03 \\
Rata-rata & 49,03 & 24 & 23 \\
Range & 47 & 7,43 & 9,54 \\
Standar deviasi & 16,98 & 73,08 \\
Varians & 288,37 & 55,292 & 233,08 \\
\hline
\end{tabular}

Tabel 3. Hasil pretest dan posttest kelas eksperimen 2 (metode discovery)

\begin{tabular}{llll}
\hline Statistik & Pretest & Posttest & Selisih \\
\hline Jumlah siswa & 30 & 30 & 30 \\
Skor & 65 & 76 & 76 \\
maksimum & & 43 & 27 \\
Skor minimum & 16 & 2979 & 1675 \\
Jumlah & 1304 & 45,97 & 22,50 \\
Rata-rata & 43,47 & 65,97 & 16 \\
Range & 49 & 33 & 7,55 \\
Standar deviasi & 17,58 & 10,02 & 208,63 \\
Varians & 309,22 & 100,58 & \\
\hline
\end{tabular}

Untuk melihat besarnya perbedaan nilai siswa kelas eksperimen 1 dan kelas eksperimen 2 sebelum dan setelah perlakuan digunakan rumus $\left(\mathrm{O}_{2}-\mathrm{O}_{1}\right)-\left(\mathrm{O}_{4}\right.$ $\left.0_{3}\right)=(96-72)-(33-24)=9$. Berdasarkan perhitungan tersebut diketahui bahwa perbedaan hasil belajar antara kelas eksperimen 1 dan kelas eksperimen 2 adalah 9. Kemudian, dicari nilai perbandingannya dengan rumus: $\left(\mathrm{O}_{2}-\mathrm{O}_{1}\right) /$ $\left(\mathrm{O}_{4}-\mathrm{O}_{3}\right)=(96-72) /(76-43)=24 / 33$ atau $33 / 24=1,375$. Berdasarkan perhitungan tersebut diketahui bahwa besar perbandingan hasil belajar antara kelas eksperimen 1 dan kelas eksperimen 2 adalah 1,375 .

\section{Pembahasan}

Hasil penelitian diperoleh melalui tes akhir berbentuk essay dari 15 butir soal. Setelah diuji cobakan dan dianalisis 15 soal tersebut dipakai serta dilakukan untuk menguji kemampuan pada kedua subyek penelitian.

Dari perhitungan statistik data awal pada saat pelaksanaan pretest, diperoleh nilai rata-rata tes awal kelas eksperimen $1\left(\mathrm{X}_{1}\right)=49,03$, dengan simpangan baku $(\mathrm{Sd})=17,58$. Dari data tes awal tersebut 
diketahui bahwa kemampuan rata-rata kelas masih rendah dan belum ada siswa yang memperoleh nilai di atas KKM. Kedua kelas penelitian belum mendapatkan materi pembelajaran, sehingga belum ada siswa yang berhasil mencapai KKM. Hal ini membuktikan bahwa kemampuan awal siswa adalah sama dan siap untuk mendapatkan perlakuan.

Setelah diketahui kelas tersebut berangkat dari kondisi awal sama, kemudian kedua kelompok diberi perlakuan yang berbeda, pada kelas eksperimen 1 menggunakan metode pembelajaran inquiry dan kelas eksperimen 2 menggunakan metode pembelajaran discovery. Setelah pembelajaran pada kelas eksperimen 1 dan eksperimen 2 selesai, dilanjutkan dengan pemberian posttest pada kedua kelas.

Berdasarkan hasil tes dari soal posttest yang dilakukan, diperoleh ratarata hasil belajar kelas eksperimen $1(\mathrm{X})=$ 80,13 , dengan simpangan baku $(\mathrm{Sd})=$ 7,43 , sedangkan untuk data posttest eksperimen 2 diperoleh rata-rata hasil belajar eksperimen $2(\mathrm{X})=65,97$, dengan simpangan baku (Sd) = 10,02. Berdasarkan nilai rata-rata pretest dan posttest kelas eksperimen 1 dan kelas eksperimen 2 diketahui bahwa terdapat perbedaan rata-rata antara kedua kelas yaitu sebesar 9 dengan perbandingan sebesar 1,37. Perbedaan ini disebabkan dari perlakuan kelas eksperimen 1 yang menggunakan metode pembelajaran inquiry sementara di kelas eksperimen 2 menggunakan metode pembelajaran discovery.

Hasil uji hipotesis menggunakan ujit. Dari hasil uji-t diperoleh thitung senilai 2,39 . Berdasarkan tabel distribusi t pada $a=0,05$ dengan derajat kebebasan $\mathrm{n}_{1}+\mathrm{n}_{2}$ $-2=30+29-2=57$ maka diperoleh $t_{\text {tabel }}$ senilai 2,00. Jadi, thitung $>t_{\text {tabel }}$ maka $\mathrm{H}_{0}$ ditolak yang berarti $\mathrm{H}_{1}$ diterima. Hasil analisis tersebut membuktikan bahwa terdapat perbedaan yang signifikan dari kedua kelompok. Dimana rata-rata hasil belajar siswa pada materi sistem ekskresi pada manusia yang diajar dengan metode pembelajaran inquiry lebih baik dibandingkan dengan siswa yang diajar dengan metode pembelajaran discovery.

Perbedaan hasil belajar yang diperoleh siswa antara kelas eksperimen 1 dengan kelas eksperimen 2 disebabkan karena adanya perbedaan dalam cara pembelajarannya. Dalam penelitian ini, hasil belajar siswa yang menggunakan metode pembelajaran inquiry lebih tinggi dari pada hasil belajar siswa yang menggunaan metode pembelajaran discovery.

Melalui observasi, terlihat suasana belajar pada kelas eksperimen 1 yang diberikan dengan perlakuan metode pembelajaran inquiry lebih aktif dan bersemangat. Metode pembelajaran inquiry pada dasarnya menekankan proses berpikir secara kritis dan analitis untuk mencari dan menemukan sendiri jawaban dari suatu masalah yang dipertanyakan. Hal ini senada dengan Sanjaya (2012), bahwa proses berpikir itu biasanya dilakukan melalui tanya-jawab antara guru dan siswa. Siklus inquiry dilakukan dari kegiatan mengamati, bertanya, menyelidiki, menganalisa dan merumuskan teori baik secara individu maupun bersama-sama dengan teman lainnya. Teori tersebut didukung oleh pendapat Arsad \& Raya (2011), yang menyatakan bahwa pendekatan inquiry adalah pendekatan mengajar dimana siswa merumuskan masalah, mendesain eksperimen, mengumpulkan dan menganalisis data sampai mengambil keputusan.

Pembelajaran dengan metode inquiry memberikan kesempatan kepada siswa untuk terlibat secara aktif dalam menemukan sendiri pemecahan masalah yang dihadapi dan mencoba menarik kesimpulan sendiri. Teori ini diperkuat lagi oleh Mulyasa (2013), dalam metode pembelajaran inquiry, permasalahan dilontarkan oleh guru, cara pemecahan masalah ditentukan oleh siswa, penemuan kesimpulan juga dilakukan oleh siswa. Pembelajaran dengan melibatkan siswa secara langsung dalam menemukan konsep-konsep sebagai suatu aktivitas mental dapat memberikan kesan, sehingga pengetahuan yang diperoleh tidak mudah dilupakan dan 
siswa lebih mudah memahami materi yang disajikan. Dengan demikian, bisa disimpulkan bahwa pengetahuan dan pemahaman siswa tentang materi sistem ekskresi pada manusia dapat terbentuk. Atau dengan kata lain, proses tanyajawab antara guru dan siswa meningkatkan hasil belajar siswa pada materi sistem ekskresi pada manusia.

Berbeda halnya dengan metode pembelajaran discovery yang lebih menekankan pentingnya pemahaman struktur terhadap suatu disiplin ilmu melalui keterlibatan siswa secara aktif dalam proses pembelajaran. Artinya bahwa dalam proses pembelajaran, siswa menjadi pusat pembelajaran (student centered) sedangkan guru hanya sebagai pembimbing dan fasilitator. Pemahaman ini senada dengan pendapat Bruner (dalam Udin, 2011), bahwa pembelajaran discovery adalah suatu proses belajar yang didalamnya tidak disajikan suatu konsep dalam bentuk jadi (final), melainkan siswa dituntut untuk mengorganisasi sendiri cara belajarnya dalam menemukan konsep. Sedangkan menurut Ilahi (2012), dalam metode pembelajaran discovery, guru hanya bertindak sebagai pembimbing dan fasilitator yang mengarahkan siswa untuk menemukan konsep, dalil, prosedur, algoritma dan semacamnya; mengutamakan cara belajar siswa aktif, berorientasi pada proses, mengarahkan sendiri, mencari sendiri dan refleksi. Siswa menggunakan pengalaman mereka terdahulu dalam memecahkan masalah dengan berinteraksi untuk menggali, mempertanyakan selama bereksperimen dengan teknik trial and error. Metode demikian kurang efektif diterapkan pada materi sistem ekskresi pada manusia, karena materi sistem ekskresi pada manusia membutuhkan pendampingan, diskusi, dan keterlibatan guru dengan siswa dalam memecahkan masalah.

Materi sistem ekskresi pada manusia sangatlah kompleks, karena mengandung banyak konsep yang bersifat abstrak sehingga pendampingan dan peran serta guru bersama-sama siswa dalam memecahkan masalah sangatlah diutamakan. Pemahaman beberapa ahli tersebut selanjutnya didukung pula dengan penelitian terdahulu dari Suherman (2013), yang menyatakan bahwa hasil belajar siswa yang menggunakan model inquiry learning lebih tinggi dari pada model pembelajaran discovery learning dalam meningkatkan hasil belajar siswa pada materi sistem pencernaan manusia.

Berdasarkan hal tersebut, dapat dilihat perbedaan hasil belajar antara kelas yang diajarkan dengan metode inquiry dan kelas yang diajarkan dengan metode discovery. Hasil belajar yang dimaksudkan disini adalah hasil yang dicapai oleh peserta didik berupa angka atau skor setelah menyelesaikan tes yang diberikan.

Hasil belajar adalah perubahanperubahan yang terjadi pada diri peserta didik, baik yang menyangkut aspek kognitif, afektif, dan psikomotor sebagai hasil dari kegiatan belajar. Dalam kegiatan pembelajaran atau kegiatan instruksional, biasanya guru menetapkan tujuan belajar. Anak yang berhasil dalam belajar adalah yang mencapai tujuantujuan pembelajaran atau tujuan instruksional (Hamalik, 2013).

Proses pembelajaran merupakan salah satu kunci keberhasilan pendidikan dimana pendidikan merupakan pengembangan potensi dalam menyiapkan peserta didik melalui kegiatan bimbingan, pelajaran dan latihan bagi peranannya di masa yang akan dating (Dahlan, 2016).

Rata-rata hasil belajar dengan menggunakan metode discovery - inquiry adalah 82,58 dan metode ceramah bervariasi adalah 76,87 . Hasil penelitian ini didukung oleh Rokhayati (2010), bahwa metode pembelajaran guided discovery-inquiry dapat meningkatkan penguasaan konsep matematika siswa kelas VII SMP N 1 Sleman.

Dengan demikian, berdasarkan uji t diketahui bahwa kedua kelas sampel memiliki rata-rata skor posttest yang berbeda karena sudah diberi perlakuan terhadap kelas eksperimen 1 dan eksperimen 2. Dari skor rata-rata tersebut maka dapat disimpulkan bahwa hasil belajar siswa yang menggunakan 
metode pembelajaran inquiry lebih tinggi dari pada metode pembelajaran discovery pada siswa kelas VIII SMP Negeri 3 Tondano.

\section{KESIMPULAN}

Berdasarkan hasil penelitian dapat disimpulkan bahwa terdapat perbedaan rata-rata hasil belajar siswa pada materi sistem ekskresi pada manusia antara kelas yang menggunakan pembelajaran dengan meteode inquiry dan kelas yang menggunakan pembelajaran dengan merode discovery.

\section{DAFTAR PUSTAKA}

Arsad, B. \& Raya, A. (2011). Pengaruh Pendekatan Inquiry dan Discovery Terhadap Hasil Belajar Biologi Siswa Kelas XI SMA Negeri 1 Walenrang. Bionature, 12(2).

Dahlan, A. A. (2016). Penilaian Hasil Proses Belajar Mengajar. Bandung: Remaja Rosdakarya.

Hamalik, O. (2013). Proses Belajar Mengajar. Jakarta: Bumi Aksara.

Ilahi, M. T. (2012). Pembelajaran Discovery Strategi Pembelajaran. Bandung: Refika Aditama.

Mulyasa. (2013). Menjadi Guru Profesional: Menciptakan Pembelajaran Kreatif dan Menyenangkan. Bandung: Remaja Rosdakarya.

Rokhayati, N. (2010). Peningkatan Penguasaan Konsep Matematika Melalui Model Pembelajaran Guided Discovery-Inquiry Pada Siswa Kelas VII SMP N 1 Sleman. Skripsi. Yogyakarta: Universitas Negeri Yogyakarta.

Sanjaya, W. (2012). Metode Pembelajaran Beorientasi Standar Proses Pendidikan. Jakarta: Kencana.

Suherman. (2013). Teori Belajar dan Pembelajaran. Jakarta: Rineka Cipta.

Tompo, B., Ahmad, M. A. \& Muris, M. (2016). Pengembangan Model Pembelajaran Discovery-Inquiry Untuk Mereduksi Miskonsepsi IPA Peserta Didik SMP. Jurnal Sains dan Pendidikan Fisika, 12(3), 240-253.

Udin, S. (2011). Inovasi Pendidikan. Bandung: Alfabeta. 